\title{
The fight against the anti-nation' as a historical mission: the delegitimization of the enemy in Italian Fascism and Spanish Fascism
}

\author{
A luta contra a'antinação' como uma missão histórica: a deslegitimação do inimigo no \\ fascismo italiano e no fascismo espanhol
}

La lucha contra la'anti-nación' como una misión histórica:la deslegitimación del enemigo en el fascismo italiano y el fascismo español

Giorgia Priorelli

\section{Abstract}

For the Italian Partito Nazionale Fascista (Pnf) and the Falange Española (Fe), the political community coincided with the nation, conceived not as an undifferentiated conglomeration of citizens but as a community of believers in a 'religion of the Fatherland'. The common goal of the Italian and the Spanish fascists, since their appearance on the political scene of their respective countries, was the defence of national values. But the claim to being the only and exclusive representatives of those values denied any effective freedom of dissent, even to those who respected national values but intended them in a different way. This article will analyse how the ideologues of the Pnf and the Fe articulated their respective campaigns against the anti-national enemies in order to legitimise their own parties and pave the way to the effective realization of their own nations: nations that had to be clearly and totally fascist.

Keywords: Fascism. Falangism. Nation.
Doutora em Ciência Política pela Universidade Luiss Guido Carli - Roma, Itália. E-mail: gpriorelli@luiss.it

Recebido em 03/5/2018 - Aprovado em 24/5/2018 http://dx.doi.org/10.5335/hdtv.18n.3.8600 
The shout of your fully legitimate exultation fuses together with the one rising from all the cities of Spain, that now are completely liberated by the infamy of the reds, and with the shout of the anti-Bolsheviks from all over the world. The wonderful victory of Barcelona is another chapter in the history of the new Europe we are creating. Franco's magnificent troops and our intrepid legionnaires did not defeat only Negrín's government; many others among our enemies at this moment are biting the dust. The watchword of the reds was this: "No pasarán"; we passed, and I tell you we will pass (MUSSOLINI, 1951, p. 283).

This was how Mussolini, on the balcony of the Hall of the Globe in Palazzo Venezia, addressed the crowd gathered in the square on January 26, 1939, to celebrate 'the entrance of the nationals' in the Catalan capital under the command of the generalissimo (MUSSOLINI, 1951). The fall of Barcelona, which was one of the last strongholds of the Popular Front, represented a great victory both for the insurgent military formation and the Duce of Italian Fascism. This was not only because it rewarded the support that the black shirts of the Corpo Truppe Volontarie (Corps of Volunteer Troops or Cvt) had given since the first weeks of the Spanish Civil War. It was also not only a payback for the stinging setback - which had a strong symbolic and propaganda value - suffered in March 1937 in Guadalajara by the militias led by Mario Roatta, who supported the weight of the operation to a great extent. ${ }^{1}$ Above all, it was the triumph of the true and only Spanish nation, the fascistized nation of Francisco Franco, against the anti-nation, fed by Socialism, of the liberal-republican governments.
Mussolini's speech was genuinely paradigmatic because it highlighted an important element in the ideologies of both the Pnf and the Falange: the fierce struggle against the 'anti-national enemy' until its annihilation. This was a political constant in the two Fascisms, since it referred to a common historical mission.

In Italy, since the years preceding the March on Rome, the movimento Sansepolcris$t a$ had built its political fortunes on presenting itself as the bulwalk against widespread Bolshevism. As Roberto Vivarelli pointed out, Mussolini succeeded because the Fasci Italiani di Combattimento and, then, the Pnf appeared to many as defenders of the national State, whose values were denied by Socialist maximalism, which drew inspiration from Soviet Russia as its own elective homeland (VIVARELLI, 2012, p. 24-25, p. 321-323). The campaign against the anti-national enemies was from the beginning a merciless battle, whose intensity changed over time, in inverse proportion to growing Italian support for Fascism. At the point of the regime's maximum consolidation, when it seemed that all opposition had been eliminated, the emphasis on the internal opponents diminished. Then it became stronger in particularly unfavourable, even if not really dramatic circumstances, as it happened after the collapse of the regime and during the tragic two-year period 1943-1945.

In Spain, the Falangist struggle against anti-national enemies started with the foundation of the party in 1933, even if it had its forerunner in the Jons of Ramiro Ledesma Ramos and Onésimo Redondo Ortega. However, it was the Civil War - fought by 
the 'crusaders' of the nationalist troops in the name and for the salvation of the homeland - that represented 'the greatest nationalizing and denationalizing episode of the Spaniards. At that moment, the Spanish nation's combat against 'anti-Spain' became a battle of not only the Falange - which meanwhile had become an armed militia and a mass party in the territories controlled by the latter - but also of the whole Francoist front. ${ }^{2}$ In Ismael Saz's opinion, the one fought in 1936-1939 was 'the most total war among all the civil wars of contemporary Spain.' (CAMPOS, 2003, p. 158). But, as the Valencian historian has argued, if 'the war was total, even more was the victory', since it allowed the nationalists to appear as the 'incarnation of the authentic Spain' and to marginalize the defeated by treating them as the sworn enemies of the homeland (CAMPOS, 2003, p. 159).

The persecutory fury against the anti-nation decreased partially after the victory of the generalísimo in 1939, and even more with the diminished influence of the camisas azules in the government, as a consequence of the historical events, previously mentioned, which took place between the spring of 1941 and the summer of 1942. These events sanctioned the failure of the 'appropriation of Spain and the homeland' by the party that, after merging with the traditionalists in April 1937, had changed its name to Fet de las Jons. The reconfirmation of the Christian roots of the regime and the resulting total identification of the homeland and Catholicism' ratified the completion of the project to create a Spanish Fascist State on the Italian model, as well as the dominance of the other main political culture in Francoism - the National Catholic one - and 'a considerable reduction of the patriotic lexicon.' (CAMPOS; ARCHILÉS, 2014, p. 272).

A note of caution is needed here, however: the fact that both the Pnf and the Falange at the end failed to complete their own plans of 'integral fascistization' of the nation does not diminish the central role that the war against internal enemies played in the ideology of the two parties; a war that, both in Italy and Spain, hit dramatically violent peaks (GENTILE, 2011, p. 184).

By exploiting its legitimate and cohesive potential, black shirts and blue shirts did everything to identify themselves with the nation, and tried to interpret the idea of the homeland fascistically until the end. So the abbrochment of the nation by the Pnf corresponded to a similar process in the ideological universe of the Falange (GENTILE, 2011, p. 156-160). In both cases, the consequence was inevitably the same: discrimination against those who - while being Italian and Spanish citizens in all respects - held a different view of what their country was, its founding values, and its historical mission. In fact, thinking of the nation in terms other than those proposed by Fascist and Falangist ideologues represented a betrayal resulting in the exclusion of the reprobates from the national community (DI NUCCI, 2003, p. 127-130).

Certainly, one could argue that the battle against internal enemies was not an exclusive ideological component of Fascism, since it was also present in the political culture of other movements, parties and regimes of opposite political nature. Yet, in the 
two cases analysed here, the ideological war between nation and anti-nation - in which 'two Italys' and 'two Spains' fought each other within the boundaries of the State was dramatized to an extreme, with an extraordinary centrality.

The clash, as ideologically configured by the Pnf and the Falange, was a struggle of liberation from opponents who, although members of the same State group, were perceived as foreigners at home. Deprived of their status as citizens and sometimes treated as genuine pariahs, those considered anti-nationals were physically and morally excluded from the community (DI NUCCI, 2003, p. 132-133). As things stood, it was not surprising that Socialists were regarded as enemies of the nation par excellence, since they recognised themselves as members of a 'class', and championed the cause of proletarian internationalism. On closer scrutiny, however, not only were 'Bolsheviks' branded invalidators of the homeland, but so were supporters of a liberal ideology that - even if at different times and in different ways - was dismissed as anti-national.

For both the black shirts and the blue shirts, the basic anti-national character of liberalism was determined by the fact that it legitimized the exclusive domain of the bourgeoisie. In other words, they believed that the liberal State, formally representative, was actually a 'mono-class' State, and ignored the social demands of the subordinate classes (GENTILE, 2011, p. 166-167). Such a State was also deemed responsible for the foundation of an articulated network of corruption based on a solid crony structure, clearly indicating that the liberal political class was incapable of making the government work in an authentic democratic way.

The most glaring symbol of this system, judged both corrupt and corrupting, was the institution of Parliament. Considered the 'epidemic illness' of the Italian political organism by Pnf ideologues, it was the exclusive instrument of the Giolittian 'bourgeois oligarchy', which promised with 'demagogic perfidy' to fight for the upliftment of the people, but instead governed essentially for the 'favours of the clienteles' (D'ANDREA, 1927, p. 300; CASINI, 1924, p. 724).

For their part, the Falangists accused the republican government led by Azaña, seen as heir to the tradition of Spanish $\mathrm{Ca}^{-}$ ciquismo, of various forms of nastiness. The vortex of radicalization in which the country had fallen was attributed to its incompetence; a radicalization produced by the demand for more social justice, coming mainly from the peasant population, to which the Republic was unable to give an adequate response (RANZATO, 2012, p. 151-169).

In both Italy and Spain, for the two Fascisms, the liberal State was a synonym for division, certainly not nation. The roots of the disintegration lay in individualistic theory, that was the expression of the rationalist culture of the late 19th Century, of which liberal-democracy was in many ways a manifestation. Man as the centre of life was considered by the magazine Gerarchia as 'the basic error of materialistic philosophical thought' and the main character in the disunity of modern civilization. His 'hyperbolic affirmation' had transformed the State into a mere instrument for the protection of civil 
rights and negative freedoms of individuals; it had deprived citizens of a superior leadership; and, even worse, it had obfuscated the supreme reality of the nation (SELVI, 1926, p. 235-236).

In the context of such an interpretation, Italian Fascists denounced the dramatic reality constituted by the antithesis between the 'false Italy' of the executive elite and the 'real Italy' of the people gathered in the squares. In the opinion of political figures like Enrico Corradini, the care of national interests had given way to the ambition of men. So politics had become a 'curriculum of parliamentary professionalism' and an exaltation of the 'superstition of the majority.' (CORRADINI, 1928, p. 300; MURRI, 1924, p. 704).

Similarly, Spanish Fascists condemned the republican government that, in their eyes, had only been concerned with producing laws and speculating abstractedly on the individual, with the result that the 'national genius' had become more than anything else an 'issue of numbers.' (RAMOS, 1933, p. 582-584). The liberal State, devoid of any ideal impulse, was not 'the resolute executor of patriotic destinies' but 'the spectator of electoral fights.' As José Antonio Primo de Rivera stated, in the years of the Republic there was:

The farce of the ballots in a glass urn [that] had the virtue of telling us at any instant if God existed or did not exist, if the truth was the truth or not the truth, if the homeland had to remain or if it was better for it, in a moment, to commit suicide (RIVERA, 1976, p. 189).

In the interpretation of some, it seemed that, in such a 'turbulent and unpleasant life', there was a deep laceration of the social connective tissue and the bond of brotherhood between citizens without equal in the history of the country (RIVERA, 1976, p. 18). What emerged in the ideological reconstruction of the Falange intellectuals was the drama of a 'sectarian and rancorous' politics, inaugurated on April 14, 1931 and founded on a constitution that gave a 'legal semblance to the most anti-national State that Spain ever had.' (FERNÁNDEZ-CUESTA; SERRANO, 1938, p. 31-32).

In the thought of the Pnf and Falange ideologues, the clear separation between 'legal country' and 'real country' ended up facilitating the appearance of an intrinsically anti-national political actor: maximalist Socialism. The liberal political class had proven to be incapable of integrating the masses into the State and of providing an adequate response to their needs. Inevitably, this incapacity made the Bolshevik danger stronger day by day, and this occurred within both Italian and Spanish territorial boundaries.

From day one, Mussolini and the Fascist leaders dragged Giolitti to the dock since, in their eyes, he represented not only the 'parecchista' of the Great War, but was also the one who had sought to include the Socialist Party in the government. As is well kno$\mathrm{wn}$, the pressures from the maximalist wing of the party pushed the leader Filippo Turati to reject the invitation. But this rejection was not enough to mitigate the political hatred that the Fasci Italiani di Combattimento had for the Piedmontese statesman. They did not like the Giolittian opening to the Socialist Party at all, considering it a deplorable choi- 
ce since it represented another step towards the disintegration of the nation.

In other words, the liberal State was accused of sitting by and watching the Psi advance. The overwhelming victory of the latter in the 1919 elections and the events of the 'red biennium', interpreted by the Duce as a 'criminal attempt to caporettise Italy', corroborated that conviction. ${ }^{3}$ The climate of tension and violence made it seem like the country was on the brink of civil war and that a spark could start it. Although Bolshevism had never seemed as threatening as in those years, Giolitti merely brought the dispute back to the syndical field, hoping that attempting to resolve the crisis in the mould of parliamentary debate would be enough to return to normality. But the fact is that internal divisions in the Psi and the emergence of anti-Socialist blocs in the fall 1920 administrative elections created optimum conditions for a relaunch of Fascist action. Taking advantage of the favourable situation, the leaders of the provincial squadrismo set off a large-scale offensive, which even the signing of the pact of pacification on August 2, 1921 could not stop (DI NUCCI, 2009, p. 36-41).

In Spain, the results of the April 1931 elections - determining the victory of the republican-Socialist coalition - raised concerns that, along with the Republic, the Bolshevik revolution was also coming. While the Socialists in Italy always adopted clear revolutionary positions, which prevented any agreement with bourgeois-democratic forces for fears that a proletarian dictatorship might arise, things worked differently in Spain. Liberals and Socialists there found common ground in the struggle against the oligarchy of old Spain, and were united in support of the republican cause.

After Miguel Primo de Rivera's authoritarian experience and once the monarchical institution was set aside - since it was too compromised with the dictatorship to be credible in the new liberal-democratic regime - the Alcalá Zamora provisional government and the following Azaña governments seemed to be, in the eyes of the Spanish Fascists, the anteroom of hell. The struggle, as Onésimo Redondo Ortega wrote, was 'fatally of reciprocal elimination; Spain or the anti-Spain.' (ORTEGA, 1939, p. 157).

The reformist biennium of 1931-1933 strongly affected the political footprint of the Partido Socialista Obrero Español (Spanish Socialist Workers' Party or Psoe), which then held the majority of seats in Parliament and controlled three key ministries. Socialist leader Fernando de los Ríos first headed the Justice Ministry, then Public Education, and finally Beaux Arts. The 'Spanish Lenin', party president Francisco Largo Caballero, served as Minister of Labour and $\mathrm{Pu}-$ blic Welfare. Indalecio Prieto was Minister of Industry until December 1931, and then moved to the Ministry of Public Works until September 1933.

Once the term of the Confederación Española de Derechas Autónomas (Spanish Confederation of Autonomous Right-wing Groups or Ceda) government during the 1933-1935 'bienio estupido' ended, the victory in February 1936 of the Popular Front - including Psoe, the Partido Comunista Español (Spanish Communist Party or Pce), the republican Leftists, and the Pardido Obrero de Unificación Marxista (Workers' Party of Marxist 
Unification or Poum) - gave new impetus to Falangist fears, which were later reflected in the formation led by Franco.

The outbreak of the Civil War strongly radicalised the blue shirts' position. From July 18, all the labour and republican parties, regardless of the differences between them, were vilified as 'servants of Russian imperialism and lackeys of Stalin's designs.' (SEIXAS, 2006, p. 251). Accused of selling out Spain to Bolshevik tyranny, they were deemed guilty of breaking any emotional and ideal bond with the Spanish people (GAY, 1937, p. 6; SEIXAS, p. 251).

The formation of Socialist governments - the first headed by Caballero in September 1936, and the second led by Negrín in May 1937 - represented to Falangist militiamen the materialization of Bolshevik anti-Spain. At the same time, the fear of massive Soviet interference in the country was more than founded, both from a military and, above all, political point of view. In fact, at that time, Moscow not only provided arms and military advisers to the republicans but also held Spanish gold reserves, given by the government as a 'pledge' in exchange for the international protection of the Soviet Union (RANZATO, 2012, p. 455). For that reason, the blue shirts appeared more determined than ever to fight the inner enemies of the homeland. After all, as Mussolini wrote, 'the human beast is always the same, whether it is [...] a Russian ghepeù or a Spanish militiaman.' (MUSSOLINI, 1951, p. 194).

Italian and Spanish Fascists hated Socialism for many reasons, a main one being the fact that it pursued goals detrimental to the integrity of the nation. Fomenting the most extreme class antagonism and instigating the working class to fight, Socialism completely ignored the national dimension, which was sacrificed on the altar of internationalism. This was the supreme ideal to which were dedicated all the energies, in order to create a 'universal proletariat' in which States and social distinctions would no longer exist.

By placing above all the principle of international solidarity of the proletariat, Bolshevism in its several national variants subordinated loyalty to one's country to the interest of the revolution. The nation was downgraded to a territorial context: nothing more than the contingent and marginal framework of the battle of the working class to attain power and affirm its supremacy. Therefore, the internationalist doctrine nipped in the bud any possibility of synthesis between the nation and Socialism, confirming the anti-systemic nature of the latter in the eyes of both Pnf and Falange ideologues (GENTILE, 2011, p. 143-144).

In Italy, the struggle of the Fasci Italiani di Combattimento against Socialist strongholds started from the beginning of the movement, but reached a pivotal point when the black shirts met the agrarians (LOGGIA, 2010, p. 33-42). This encounter allowed Fascism to break into the political scene of the country and occupy its centre in a stable manner. As is well illustrated in Angelo Tasca's study, the agrarians found common cause with Fascism, pouring into it all the hatred and rage they had harboured since "their "vital space" [was] reduced by the development of the cooperatives and municipal Socialism.' (TASCA, 1995, p. 189-228). 
'The agrarians "discover[ed]" Fascism' in the administrative elections of October-November 1920, in which the Socialists - even if they did not repeat their incredible success in the previous year's political elections - won the majority of seats in many municipalities and provincial councils (TASCA, 1995, p. 190). ${ }^{4}$

In Emilia, the Psi victory was overwhelming, considering that it triumphed in 223 municipalities out of 280 . And that was where an alliance between the agrarians and the Fascists began to take shape. The former saw their scope for action in the countryside diminishing day by day, while the latter looked at the spread of the institutions of Socialism as a materialization of Bolshevism. So they organized expeditions to strike at these institutions, targeting 'red' municipalities, almost like they were a 'sort of Italian version of the Soviets' (DI NUCCI, 2008, p. 23-26). Under these circumstances, it was not possible to imagine any involvement of the Psi in government, as this would have meant leaving the field open to the 'destroying struggle between the classes, whose consortium is the foundation of national society.' (CORRADINI, 1923, p. 1065).

The Fascists countered 'irresponsible Bolshevik action' - which served the alien and was cause of 'despondency' - with their reorganizing and reconstructive force that, they claimed, they provided to serve the national community (MARPICATI, 1934, p. 797). In summary, in the Fascist ideologues' interpretation of the historical events of the country, the Socialists - by identifying themselves as part of the universalistic horizon of proletarian internationalism - contribu- ted to destroying the ideal of the nation. It was the Fasci Italiani di Combattimento and then the Pnf - which from the beginning had characterized themselves in terms of 'adherence [...] to the national State and to its values' rather than in terms of social class - who raised the flag of the Fatherland again and established in its name a radical new political order (CRESPI, 1929, p. 178-180; VIVARELLI, 2012, p. 31).

Similarly, the Spanish Socialists were accused of spreading the 'germs' of the dissolution of the country, prostrating themselves at the feet of the Soviet enemy. They were deemed guilty of not only conspiring against the nation and promoting the fratricidal struggle between the classes, but also of undermining its territorial and spiritual unity. In fact, the Psoe, in addition to fighting for the ideal of the proletarian revolution, supported two other causes considered highly anti-national: the cause of regionalisms and the cause of the secular State. On the one hand, it showed its benevolence and support for those who served, in the eyes of the Falangists, the 'particularist ambitions of politicians and regional traffickers who [complicated] the problem of autonomies with blasphemous breaths of separatism.' (ORTEGA, 1939, p. 72). And on the other hand, it led its own atheist struggle against the Catholic Church that was 'one of the historical essences of the españolidad'; a struggle fought with the ultimate goal of eliminating the Catholic presence from society, often resorting to persecutory and vindictive methods (SEIXAS, 2006, p. 247).

The text of the Constitution of the Republic approved on December 9, 1931, ac- 
cording to the opinion of its detractors, put all this down on paper. Hastily dismissed as the 'effort of a minority' who came to power riding a revolutionary wave to 'build an anti-Spanish State', the Constitution was considered a sort of ideological manifestation of anti-national ideals, concretely translated into articles that defined the organization of State powers. In fact, the Constitution attributed wide administrative autonomy to regions that had applied for it, recognizing the Statutes of self-government, as happened in Catalonia in 1932. Moreover, it also established a wide separation between the State and the Church; guaranteed freedom of worship; provided for a drastic reduction in ecclesiastical privileges; and sanctioned the dissolution of religious orders that had vowed obedience to an authority other than the State. As if that was not enough, it legitimized civil marriage and divorce, and protected the rights of children born outside marriage (RODRÍGUEZ, 1934, p. 183).

The decisively reformist, if not radical, character of the Constitution angered Spanish Fascists, who saw in it an attempt - not even veiled - to sow seeds of discord and expunge the spiritual element from the lives of Spaniards. 'Tyrannical' and 'unstable', Socialism was accused of being the reason for the 'perversions, weaknesses and repugnant deficencies which had profaned the Nation, the unstoppable deterioration of health, and the inadmissible debasement of the most intimate national sentiment.' (ORTEGA, 1939, p. 51; ROMERO, 2008, p. 138).

Dragged to the dock, the Psoe was charged with pitting Spaniards against one another by creating a divisive policy that, on the one hand, exploited tools that 'liberal-parliamentary candour' offered its subversive propaganda; and, on the other hand, resorted to its revolutionary systems (RAMOS, 1933, p. 582-584). In the opinion of the Falangists, the country was in the tight grip of liberalism on one side, and Bolshevism on the other. So they believed they had no choice but to 'mercilessly wipe out the internal accomplices, purple or red, who have assaulted or projected to assault the founding values, freedoms and spiritual fort' of the Fatherland in order to 'serve the nation powered by hidden masters. ${ }^{5}$

Significantly, among these 'hidden masters', both Italian and Spanish Fascists included Freemasonry, completing the list of anti-national opponents. Associated at different times with the liberal regime and with Socialism, it seemed to share with both of them a potentially disintegrating, subversive and anti-systemic character. According to an historical interpretation, Masonic lodges were accused of moving the levers of world finance. But for the Pnf and the Falange, the worst thing was that they plotted in the shadows to control the vital ganglia of the State. So Freemasonry was considered a serious threat that had to be counteracted with appropriate measures.

The first one was Italian Law no. 2029 of November 26, 1925, better known as the 'Law on secret societies'. This included the dismissal of all civil servants and military agents of every order and rank of the State, provinces and municipalities or institutes under their protection, belonging to organizations established in the Kingdom or outside it, even partly operating in a clandestine 
manner or whose members were bound to the secrecy. ${ }^{6}$ The reference to 'that great criminal conspiracy and forge of high treasons that was Freemasonry' was explicit (PAVESE, 1934, p. 263). ${ }^{7}$

Actually, the lodges in Italy were not a real danger. From the data reported by the Minister of Justice and Religious Affairs at that time, Alfredo Rocco, it was evident that the number of Freemasons in 1925 did not exceed twenty thousand. Nonetheless, party theorists were convinced that the power of the Grand Orient was spreading on the peninsula like a disease attacking the healthy body of the nation, enfeebling the spirit of the people, and weakening the authority of the Pnf from the inside. Hence the dangerous character attributed to Freemasonry, which 'was clinging to the State and, in a thousand ways, was binding it and dominating it.' (ROCCO, 1927, p. 40).

The struggle against secret associations, therefore, constituted a relentless fight to defend the State and the nation. In fact, it was not permissible for a 'hidden hierarchy' to attempt to dominate the State hierarchy and get to a point of trying to replace it. Once the independence of the country from an alien power was 'won at such a price and at such a price maintained', it was inconceivable for the nation to find itself again at the centre of political manoeuvres orchestrated by clandestine organizations linked to foreign headquarters, which had nothing to do with the homeland of true Italians (ROCCO, 1927, p. 40). For this reason, after the definition of the legislative framework justifying the persecution, the members of the lodges were subject to the unquestionable judg- ment of a Special Court, expressly charged with the evaluation of crimes perpetrated against the State and the regime. ${ }^{8}$

Analogously, Falange theorists also avowed and strengthened the theory of Masonic conspiracy, exploiting the enormous potential for legitimization/delegitimization that it possessed. This happened from the early stages of Spanish Fascism's development. The Jonsist Onésimo Redondo Ortega, for example, in January 1933 denounced Freemasonry's strongly anti-religious, secular and 'foreign' character, which was alien to the national historical tradition. In his assessment, the liberal State itself as well as Marxism and the Republic represented 'export goods recommended by the Masonic lodges and the insurgent Internationals to impose upon the nation some myths and laws that [deformed] it.' (ORTEGA, 1933, p. 6).

Two years later, Falange founder José Antonio Primo de Rivera, speaking of the anti-national policy implemented during the 'terrible biennium' 1931-1933, highlighted how Spain had become a colony of Freemasonry, and legitimized the use of force against what he called a 'triumphant sect, seeder of discord, denier of the national community and obedient to foreign orders.' (RIVERA, 1976, p. 581). Advancing from the same premises, Ramiro Ledesma Ramos accused 'secret and exotic' Freemasonry of being closely related to liberal-democracy. In accordance with this affiliation, the latter had contributed to worsening the economic crisis and undermining the vital interests of the nation, public order, internal security and social peace (RAMOS, 1935). 
The intensity with which Spanish Fascists conducted this campaign, even before the Alzamiento, gave new impetus and renewed vigour to the anti-Masonic radicalism of Franco and his army during the Civil War years (ARRIBAS, 2009, p. 180-184). This meant a strong Falangist influence underlying the normative measures taken during the conflict and in its aftermath, which were clearly aimed at annihilating the lodges as secret associations and, above all, as enemies of the nation. Hit by censorship along with the Popular Front and trade unions, they were officially banned by the Ley de Responsabilidades Politicas of February 9, 1939, which reiterated Freemasonry's illegal and anti-national character. ${ }^{9}$ The legislation targeted parties and groups that had contributed to creating or aggravating subversion of the order in Spain, and all those who had opposed the nationalists 'with concrete acts or serious passivity. ${ }^{10}$

A new law, promulgated on March 1, 1940, intensified the persecution. This legislative provision affected secret societies and international forces of a 'clandestine nature' - essentially Freemasonry and seditious organizations associated with it - since it was thought that they constituted the galaxy of international Communism. To justify the law that led to another repressive crackdown, many reasons already adduced several times before were given. The organizations in question were held responsible for all the tragedies that devastated the life of the nation: from the war of independence to the loss of the colonial empire, from the fall of the constitutional monarchy to the 'terrible atheistic, materialist, anti-militarist and anti-Spanish campaign' that made Spain a 'satellite and slave of the criminal Soviet tyranny' during the 1930s. ${ }^{11}$

Members of the lodges were considered guilty of providing support, arms and money to republican oppressors and, along with the Communists, were accused of spreading 'the most atrocious slander against true Spain.' Like what happened in the Italian Fascist regime, a Special Court was established to judge those suspected of affiliation with Freemasonry. This court also had the discretion to award 'excusas absolutorias' ('absolving justifications') provided by law for special merits, essentially linked to participation in the nationalist cause. ${ }^{12}$

Falling within the ambit of the punitive measures' exclusion clauses, support for the Falange - that was a fundamental component of the nationalist front since the early months of the Civil War - ended up being a parameter to identify a good citizen, and its absence a discriminating factor for assigning the black mark of 'anti-national Spaniard'. Moreover, although there is no doubt that the regime never granted Falangists an appropriate space of political manoeuvre to implement a 'genuinely Fascist direction' in governing the country, it is also true that the reward nature of certain articles in the March 1, 1940 law surely had something to do with the efforts of the blue shirts who, since their origins, had attempted to affiliate Falange with the true homeland (CAMPOS, 2004, p. 167; PAYNE, 1965, p. 163-167).

So it can be said advisedly that the blue shirts' ideologists conceptualized the image of the anti-national enemy in a form very similar to what the Fasci Italiani di Combattimento first, and later the Pnf, did. Mono- 
polising the ideal of the Fatherland, Fascism and Falangism identified the nation with themselves. The relevance of this ideological appropriation process lies in the fact that it was not just an abstract construction of some theorists, but was turned into concrete political action aimed at realizing the most ambitious goal of the Pnf and the Falange: namely, the effective fulfilment of the Fascist nation in Italy, and the National syndicalist one in Spain.

\section{Resumo}

Para o Partido Nacional Fascista italiano (PNF) e a Falange Espanhola (FE), a comunidade política coincidia com a nação concebida, não como um conglomerado indiferenciado de cidadãos, mas como uma comunidade de crentes em uma 'religião da pátria'. O objetivo comum dos fascistas italianos e espanhóis, desde sua aparição no cenário político de seus respectivos países, era a defesa dos valores nacionais. Mas a pretensão de ser os únicos e exclusivos representantes desses valores negava qualquer liberdade efetiva de dissidência, mesmo àqueles que respeitavam os valores nacionais, mas os pretendiam de maneira diferente. Este artigo analisará como os ideólogos do PNF e da FE articularam suas respectivas campanhas contra os inimigos antinacionais a fim de legitimar seus próprios partidos e preparar o caminho para a efetiva realização de suas próprias nações: nações que deveriam ser clara e totalmente fascistas.

Palavras-chave: Falangismo. Fascismo. Nação.

\section{Resumen}

Para el Partito Nazionale Fascista italiano y la Falange Española, la comunidad política coincidió con la nación, concebida no como una conglomeración indiferenciada de ciudadanos, sino como una comunidad de creyentes en una 'religión de la Patria'. El objetivo común de los fascistas italianos y españoles, desde su aparición en la escena política de sus respectivos países, fue la defensa de los valores nacionales. Pero la pretensión de ser los únicos y exclusivos representantes de esos valores negaba cualquier libertad efectiva de disidencia, incluso para aquellos que respetaban los valores nacionales pero los entendían de manera diferente. Este artículo analizará cómo los ideologos del Pnf y de la Fe articularon sus respectivas campañas contra los enemigos antinacionales para legitimar sus propios partidos y allanar el camino hacia la realización efectiva de sus propias naciones: naciones que debían ser claramente y totalmente fascistas.

Palabras clave: Falangismo. Fascismo. Nación.

\section{Notas}

1 About the Italian intervention alongside the nationalist front and the battle of Guadalajara see Payne (1965, p. 98-99, 158-161; 2012, p. 134-139); Preston (1998, p. 92-95, 150-152); Vilar (2000, p. 78-80).

2 The Civil War attributed political legitimacy to the Falange and conferred to its project of nationalization of the Spaniards the recognition and the popular approval that had so far been lacking. On the eve of the Alzamiento, indeed, the party had a rather small base of consensus. The first reason was its low political weight, conside- 
ring that in the elections of February 1936 it had just received $0.4 \%$ of votes. The second reason was the isolation in which it had been relegated: it was declared illegal in following March because of the waves of violence triggered in the country by its adepts. The third reason was the internal crisis that struck it in the fall of 1936 when, once many of its leaders were killed or imprisoned, the party lacked of a solid leadership. The electoral data is in Campos (2004, p. 71).

3 The verb 'caporettise' was used by Mussolini to mean the Psi intent to lead Italy to the catastrophe. This neologism comes from 'Caporetto', a former Italian village, now part of the Slovenian territory, where the Italian army was dramatically defeated by Austro-German forces in 1917 (MUSSOLINI, 1951-1978, p. 241).

4 With regard to the autumn 1920 administrative elections, it is important to remember that the anti-Socialist bloc held $56 \%$ of the votes on national basis, obtaining 4655 municipalities on 8346 and 33 provincial councils on 69 . Socialists conquered the majority in 2022 municipalities and in 26 provincial councils. The electoral data are reproduced in Gentile (2012, p. 16-17).

5 The adjective 'purple' indicates those who supported the republican cause. It refers to the purple color of one of the three horizontal stripes forming the flag of the Second republic of Spain. The quote is in Ortega (1939, p. 71). Cf. also Bravo (1937).

6 The text of the law is in Regno D'Italia (1925, p. 4714-4715).

7 (PAVESE, 1934, p. 263). It is important to note that Fascism embraced the anti-Masonic prejudice, attributable to Italian nationalism, with some difficulties. In fact, in January 1923, Mussolini was nomined 33 and was awarded the title of honorary Grand Master by Raul Palermi's Grand Lodge of Piazza del Gesù. This Grand Lodge, together with Domizio Torregiani's Lodge, not only had favoured with financial contributions the rise of Fascism, but it boasted among its members prominent figures of the movement. Fascism assumed for the first time a clearly anti-Masonic position at the IV meeting of the Grand Council of February 15, 1923 (PERFETTI, 1977, p. 266).

8 About the composition of the Special Court and its functions see Law no. 2008 of November 25, 1926, in Regno D'Italia (1926, p. 5314-5315).

9 A first measure was already taken with the edict of October 15, 1936, signed by the General Commander of the Canarian Islands, Ángel Dolla Lahoz. With it, the Freemasonry and other secret organizations were declared out of the law and all the activities related to it were labeled as 'crimes of rebellion'. The text of the edict is published in Boletín Oficial de la Provincia de Santa Cruz de Tenerife, no. 125, October 16, 1936. Two years later, a new decree issued on December 21, 1938 imposed the elimination, within a term of two months, of all the Masonic inscriptions, symbols and documents, including those in the churches and cemeteries of the national zone.

10 In Article no. 4, letter i, there was an exception for those who had abandoned Freemasonry voluntarily before July 18, 1936, and for those who had been expelled from it for having acted against the principles to which it was inspired or against the purposes it pursued (ESPANHA, 1939, p. 824847.)

11 Ley de 1 de marzo de 1940 sobre represión de la masonería y del comunismo, published in Boletín Oficial del Estado (1940, p. 1537). Cf. Arribas (2009, p. 315-322).

12 The information about the Special Court can be found in art. 12 of Ley de 1 de marzo de 1940 sobre represión de la masonería y del comunismo, above mentioned. To what concerns the excusas absolutorias, see art. 10 of the law.

\section{Referências}

ARRIBAS, Javier D. El enemigo judeo-masónico en la propaganda franquista (1936-1945). Madrid: Marcial Pons, 2009.

BRAVO, F. Camisas azules. Vértice, n. 4, special issue, July/Aug. 1937.

CAMPOS, Ismael Saz. España contra España: Los nacionalismos franquistas. Madrid: Marcial Pons, 2003.

Fascismo y franquismo. Valencia: Universidad de Valéncia, 2004.

CAMPOS, Ismael Saz; ARCHILÉS, Ferran. La nación de los españoles. Valencia: Publicacions de la Universitat de Valencia, 2014.

CASINI, Gherardo. Problema essenziale. Critica fascista, Milano, 1, Dec. 1924.

CORRADINI, Erico. Libertà e autorità. Gerarchia, n. 4, Apr. 1928. 
. Il fascismo e la riforma costituzionale. Gerarchia, n. 7, July 1923.

CRESPI, Benigno. Ordine nuovo. Critica fascista, Milano, n. 9, May 1, 1929.

D'ANDREA, Ugo. Fra libri e riviste. Critica fascista, Milano, n. 15, Aug. 1, 1927.

DI NUCCI, Loreto. Lo Stato fascista e gli italiani 'antinazionali'. In: L. Di Nucci and E. Galli Della Loggia, Due Nazioni. Legittimazione e delegittimazione nella storia dell'età contemporânea. Bologna: Il Mulino, 2003.

. Lo Stato-partito del fascismo. Genesi, evoluzione e crisi (1919-1945). Bologna: Il Mulino, 2009.

Nel cantiere dello Stato fascista. Roma: Carocci, 2008.

ESPAÑHA. Ley de 9 de febrero de 1939 de Responsabilidades Políticas. Boletín Oficial del Estado, n. 44, Feb. 1939.

. Ley de 1 de marzo de 1940 sobre represión de la masonería y del comunismo. Boletín Oficial del Estado, n. 62, Mar. 1940.

. Boletín Oficial de la Provincia de Santa Cruz de Tenerife, n. 125, Oct. 1936.

FERNÁNDEZ-CUESTA, Ramiro; SERRANO, Ramón S. Discorso pronunciato il 18 luglio 1938 dal Ministro dell' Agricultura e Segretario Generale della F.E.T. y de las J.O.N.S. a Valladolid. In: Dieciocho de Julio. Tres discursos. Ediciones Arriba, 1938.

GAY, Vicente. Estampas rojas y caballeros blancos. Burgos: Hijos de Santiago Rodriguéz, 1937.

GENTILE, Emilio. E fu subito regime: Il fascismo e la marcia su Roma. Roma - Bari: Laterza, 2012.

La Grande Italia: Il mito della nazione nel XX secolo. Roma - Bari: Laterza, 2011.

LOGGIA, Ernesto G. D. Tre giorni nella storia d'Italia. Bologna: Il Mulino, 2010.
MARPICATI, Arturo. Dall'antipartito al Partito Nazionale Fascista. Gerarchia, n. 10, Oct. 1934.

MURRI, Romolo. L'essenza della democrazia. Critica fascista, Milano, n. 22, Nov. 15, 1924.

MUSSOLINI, Benito. Siamo passati e vi dico che passeremo. In: E. Susmel; D. Susmel. Opera omnia di Benito Mussolini. Firenze: La Fenice, 1951-1963. v. XXIX.

. Caporettismo. In: Opera omnia di Benito Mussolini. Firenze: La Fenice, 1951-1978. v. XIII.

. Trecentoventi. In: Opera omnia di Benito Mussolini. Firenze: La Fenice, 1951-1978. v. XXVIII.

ORTEGA, Onésimo R. La nueva política, June 5, 1933. In: El estado nacional. Madrid: Ediciones F. E., 1939.

. Señales del estado antinacional. December 19, 1932. In: El estado nacional. Madrid: Ediciones F. E., 1939.

Ensayo sobre el nacionalismo. July 18, 1932. In: El estado nacional. Madrid: Ediciones F. E., 1939.

Signos del nuevo movimiento. Igualdad, Madrid, n. 9, Jan. 9, 1933.

PAVESE, R. Le tappe della Rivoluzione. Critica fascista, Milano, n. 14, July 15, 1934.

PAYNE, Stanley G. Falange: Historia del fascismo español. Barcelona: Ruedo Ibérico, 1965.

. The Spanish Civil War. Cambridge: Cambridge University Press, 2012.

PERFETTI, Francesco. Il nazionalismo italiano dalle origini alla fusione col fascismo. Bologna: Cappelli, 1977.

PRESTON, Paul. La guerra civile spagnola. 19361939. Milano: Mondadori, 1998.

RAMOS, Ramiro L. Ideas sobre el Estado. Acción Española, Madrid, n. 24, Mar. 1, 1933. 
. Intervención de J. A. Primo de Rivera en el Parlamento. Arriba, Pamplona, n. 1, Mar. 21, 1935.

RANZATO, Gabriele. L'eclissi della democrazia: La guerra civile spagnola e le sue origini 19311939. Torino: Bollati Boringhieri, 2012.

REGNO D'ITALIA, Gazzetta Ufficiale del. n. 277, part I. Nov. 28, 1925.

n. 281, part I. Dec. 6, 1926.

RIVERA, José A. P. Escritos y discursos. Obras completas (1922-1936). Madrid: Instituto de Estudios Políticos, 1976.

ROCCO, Alfredo. La trasformazione dello Stato. Dallo Stato liberale allo Stato fascista. Roma: La Voce, 1927.

RODRÍGUEZ, Pedro S. La tradición nacional y el Estado futuro. Acción Española, Madrid, n. 56-57, July 1, 1934.

ROMERO, Francisco C. El franquismo y los imaginarios míticos del fascismo europeo de entreguerras. Ayer, Madrid, n. 71, 2008.

SEIXAS, Xosé M. N. ¡Fuera el invasor! Nacionalismos y movilización bélica durante la guerra civil española. Madrid: Marcial Pons Historia, 2006.

SELVI, G. Le basi naturali della dottrina fascista. Gerarchia, n. 4, Apr. 1926.

TASCA, Angelo. Nascita e avvento del fascismo. Firenze: La Nuova Italia, 1995.

VILAR, Pierre. La guerra civil española. Barcelona: Crítica 2000.

VIVARELLI, Roberto. Storia delle origini del fascismo: L'Italia dallla grande guerra alla marcia su Roma. Bologna: Il Mulino, 2012. v. III. 